\title{
Function of Wildfire-Deposited Pyrogenic Carbon in Terrestrial Ecosystems
}

OPEN ACCESS

Edited by:

Samuel Abiven,

University of Zurich, Switzerland

Reviewed by:

Michael lan Bird,

James Cook University Cairns,

Australia

Xavier Domene,

Universitat Autònoma de Barcelona

Spain

${ }^{*}$ Correspondence:

Melissa R. A. Pingree

mpingree@uidaho.edu

Specialty section:

This article was submitted to

Soil Processes,

a section of the journal

Frontiers in Environmental Science

Received: 01 June 2017 Accepted: 08 August 2017

Published: 30 August 2017

Citation:

Pingree MRA and DeLuca TH (2017) Function of Wildfire-Deposited Pyrogenic Carbon in Terrestrial Ecosystems. Front. Environ. Sci. 5:53. doi: 10.3389/fenvs.2017.00053

\author{
Melissa R. A. Pingree ${ }^{1 *}$ and Thomas H. DeLuca ${ }^{2}$ \\ ${ }^{1}$ Department of Natural Resources and Society, College of Natural Resources, University of Idaho, Moscow, ID, \\ United States, ${ }^{2}$ W.A. Franke College of Forestry and Conservation, University of Montana, Missoula, MT, United States
}

Fire is an important driver of change in most forest, savannah, and prairie ecosystems and fire-altered organic matter, or pyrogenic carbon (PyC), conveys numerous functions in soils of fire-maintained terrestrial ecosystems. Although an exceptional number of recent review articles and books have addressed agricultural soil application of charcoal or biochar, few reviews have addressed the functional role of naturally formed PyC in fire-maintained ecosystems. Recent advances in molecular spectroscopic techniques have helped strengthen our understanding of $\mathrm{PyC}$ as a ubiquitous, complex material that is capable of altering soil chemical, physical, and biological properties and processes. The uniquely recalcitrant nature of $\mathrm{PyC}$ in soils is partly a result of its stable $\mathrm{C}=\mathrm{C}$ double-bonded, graphene-like structure and C-rich, N-poor composition. This attribute allows it to persist in soils for hundreds to thousands of years and represent net ecosystem $\mathrm{C}$ sequestration in fire-maintained ecosystems. The rapid formation of PyC during wildfire or anthropogenic fire events short-circuits the normally tortuous pathway of recalcitrant soil $\mathrm{C}$ formation. Existing literature also suggests that PyC provides an essential role in the cycling of certain nutrients, greatly extending the timeframe by which fires influence soil processes and facilitating recovery in ecosystems where organic matter inputs are low and post-fire surface soil bacterial and fungal activity is reduced. The high surface area of PyC allows for the adsorption a broad spectrum of organic compounds that directly or indirectly influence microbial processes after fire events. Adsorption capacity and microsite conditions created by PyC yields a "charosphere" effect in soil with heightened microbial activity in the vicinity of PyC. In this mini-review, we explore the function of $\mathrm{PyC}$ in natural and semi-natural settings, provide a mechanistic approach to understanding these functions, and examine examples of such mechanisms in published literature.

\footnotetext{
Keywords: black carbon, charcoal, carbon sequestration, surface adsorption, sorption, nutrient cycling, soil organic matter, bioactive zones
}

\section{INTRODUCTION}

In recent years, naturally occurring and anthropogenic pyrogenic carbon $(\mathrm{PyC})$ in the environment have become a prominent area of research across scientific disciplines (Zhu et al., 2005; Hammes et al., 2007; Ding et al., 2014; Lehmann and Joseph, 2015; Alam et al., 2016), and yet, to date, there has been little effort to provide a broad ranging synthesis of this unique material that transcends individual disciplines and ecosystems (Sohi et al., 2010; Hart and Luckai, 2013). An increased 
emphasis on the importance of $\mathrm{PyC}$ in the global carbon (C) cycle and as an amendment for agricultural soils has resulted in a rapid increase in the number of studies across managed, semi-natural, and natural environmental conditions affording a multi-disciplinary framework for improving our mechanistic understanding of PyC (Barrow, 2012; Santín et al., 2015; Dietrich et al., 2017). Applications of molecular spectroscopic analyses to $\mathrm{PyC}$ studies in natural environments complement the absolute quantification of $\mathrm{PyC}$ and any known information on molecular changes associated with wood pyrolysis (Nishimiya et al., 1998), transport and oxidation of PyC particles (Hockaday et al., 2006; Cheng et al., 2008; Inoue et al., 2017), change in soil organic matter quality due to wildfires (Miesel et al., 2015), and interactions of PyC surfaces with the surrounding soil environment (Archanjo et al., 2017). In this review, we describe these potential functions and explore the mechanisms underlying PyC functionality in natural and semi-natural environments for the advancement of multi-disciplinary research endeavors (see Figure 1).

\section{BELOWGROUND SEQUESTRATION OF RECALCITRANT CARBON}

Pyrogenic $\mathrm{C}$ is a high-C and low-nitrogen (N) byproduct of organic matter pyrolysis or incomplete combustion. The residual material consists of aromatic $\mathrm{C}$ rings, aliphatic $\mathrm{C}$ chains, and a variety of surface pores and cracks (Preston and Schmidt, 2006). Generally, the PyC material found in nature is less graphitic and more amorphous constituent of the black $\mathrm{C}$ continuum model (Hedges et al., 2000) which lends physical and chemical properties that convey unique functions in the soil environment.

The production of PyC by wildfires and anthropogenic fires directly adds highly recalcitrant $\mathrm{C}$ into soils, sediments, and aquatic systems in contrast to the tortuous pathway for formation of soil humic materials (Figure 1). Estimates of $\mathrm{PyC}$ persistence in soils and sediments range from hundreds to thousands of years (Meyer et al., 1995; Gavin et al., 2003; Laird et al., 2008; Liang et al., 2008), which provides evidence of wildfires in fossilized PyC from pre-Quaternary periods in the Earth's history (Scott, 2000). Accounting for PyC after fire events is an important aspect of quantifying the impact of fire on the global $\mathrm{C}$ cycle in contrasting $\mathrm{C}$ storage as $\mathrm{PyC}$ versus $\mathrm{C}$ loss as $\mathrm{CO}_{2}, \mathrm{CO}$, and $\mathrm{CH}_{4}$ during combustion events (Ciais et al., 2013). Empirical measurements of PyC in the surface and subsurface soils reported in over 500 studies suggest that $\mathrm{PyC}$ ranges from 0 to $60 \%$ of soil organic matter across forests, agriculture soils, grasslands, peat, and urban soils (Reisser et al., 2016) and yet no standard method exists to quantify PyC in soils. There are numerous PyC quantification methods commonly utilized in soils and sediments that rely on physical separation, chemical and

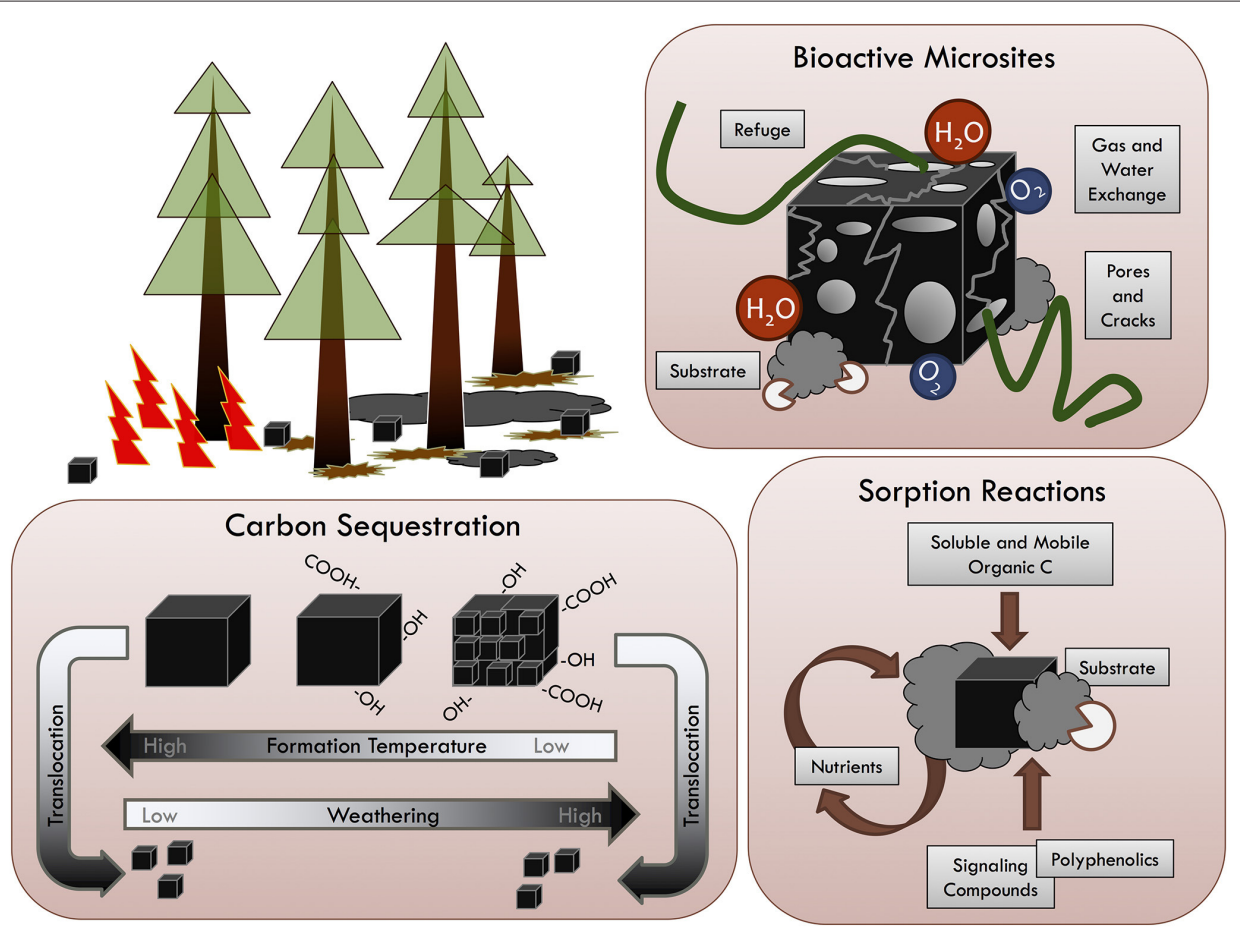

FIGURE 1 | Pyrogenic carbon (PyC) provides three primary mechanistic functions in forest soils after organic carbon (C) from aboveground vegetation is redistributed as highly recalcitrant, belowground Pyrogenic $\mathrm{C}$ via fire-driven pyrolysis and combustion. The sequestration of $\mathrm{C}$, in the form of PyC is largely driven by formation temperature and subsequent weathering (mean annual temperature and precipitation) as PyC particles oxidize, increase in oxygen and hydrogen functional groups, and are physically disintegrated and translocated over time. As a component of mineral soils, PyC can act as a sorbent of soluble and mobile organic C, nutrients, polyphenolics, plant signaling compounds, and provide substrate for microorganisms. Lastly, PyC in soils may provide bioactive zones with various pores, cracks, and physical refuge for organisms, as well as facilitate gas, water, and nutrient exchange with surrounding mineral soil. 
thermal oxidation, spectroscopy, and molecular identification (Mikutta et al., 2005; Rovira and Ramón Vallejo, 2007; Koide et al., 2011; Bird, 2015). While some methods use molecular identification of the unique $\mathrm{PyC}$ structure to separate $\mathrm{PyC}$ from humic compounds, others rely on comparisons between burned and unburned soils and are limited to a broader definition of PyC (Hedges et al., 2000).

Studies using the weak nitric acid-peroxide digestion method (Kurth et al., 2006), which quantifies chemically recalcitrant C in mineral soils, have reported $\mathrm{PyC}$ accounting for 3-25\% (with an average of 13\%) of soil C (Kurth et al., 2006; Bélanger and Pinno, 2008; MacKenzie et al., 2008; Licata and Sanford, 2012; Pingree et al., 2012; Buma et al., 2014; Soucémarianadin et al., 2014). Where unburned or pre-wildfire sites were measured in concurrence with wildfire-burned sites, $\mathrm{PyC}$ fractions accounted for $8 \%$ of total ecosystem $\mathrm{C}$ in a low fire frequency, high fire intensity subalpine forest (Buma et al., 2014), and 25\% of total ecosystem $\mathrm{C}$ in a moderate fire frequency, moderate fire intensity temperate forest (Pingree et al., 2012). The PyC on standing boles represents an additional long-term input of PyC into soil as charred bark sloughs onto the forest floor and standing snags fall to the ground (Makoto et al., 2012; Buma et al., 2014). Wildfireburned standing snags in the Alaskan boreal, USA, accounted for $65-248 \mathrm{~kg}_{\text {charcoal ha }}{ }^{-1}$ (if charcoal C is assumed $50 \% \mathrm{C}$, $33-124 \mathrm{~kg} \mathrm{C} \mathrm{ha}^{-1}$ ) in a beetle-killed Picea glauca forest (Makoto et al., 2012). Most wildfire events are likely to increase PyC storage and $\mathrm{PyC}$ as a component of total ecosystem C; however, wildfires may consume $\mathrm{PyC}$ remaining on the forest floor from prior wildfire events (Zackrisson et al., 1996; Tinkham et al., 2016).

The resistance of $\mathrm{PyC}$ to chemical and biological oxidation can largely be attributed to its stacked aromatic C structure (Pierson, 1993; Cohen-Ofri et al., 2006; Ascough et al., 2011). Short and strong sigma $(\sigma)$ bonds create one plane of hexagonal $C$ while the fourth valence electron (orthogonal to the $\sigma$ bonds) forms longer and weaker van der Waals bonds $(\pi)$ with other hybridized electrons above and below the hexagonal plane (Pierson, 1993; Kleber et al., 2015). The result is a layered, alternating hexagonal structure unique to $\mathrm{C}$.

Oxidation of $\mathrm{PyC}$ has been attributed to both the intrinsic structure of $\mathrm{PyC}$ material and environmental gradients. Temperature-dependent recalcitrance has been indirectly suggested by several laboratory incubation studies that showed reduced $\mathrm{C}$ mineralization in the presence of $\mathrm{PyC}$ produced at high temperatures (Baldock and Smernik, 2002; Bruun et al., 2008; Zimmerman, 2010; Hanan et al., 2016). These studies were unable to distinguish the effects of inherent recalcitrance from adsorption to $\mathrm{PyC}$ surfaces, which may concurrently reduce available $\mathrm{C}$ by adsorption (see next section). Long-term storage of $\mathrm{PyC}$ in soils and $\mathrm{PyC}$ elemental composition was shown to be influenced by climate variables (precipitation and temperature), which had a greater influence compared to soil characteristics (soil texture, cation exchange capacity, $\mathrm{pH}$ ), with mean annual temperature being the best predictor of $\mathrm{PyC}$ oxidation (Glaser and Amelung, 2003; Cheng et al., 2008). Aged PyC particles showed slightly lower aromaticity and released larger and more aromatic clusters into solution or as colloids, which suggests oxidation over a 10-year study period (Schneider et al., 2010). Similarly, many studies showed aged PyC particles decrease in $\mathrm{C}$ concentration and an increase in functional groups relative to fresh PyC (Hockaday et al., 2007; Cheng et al., 2008; Nguyen et al., 2008; Ascough et al., 2011; Singh et al., 2012), which possibly resulted from environmental weathering, microbial decomposition (Hockaday et al., 2006, 2007), or faunal bioturbation (Domene, 2016). PyC particles have been shown to decrease in specific surface area over time (Hockaday et al., 2007), although the physical fragmentation of larger particles may ultimately increase total surface areas in soil. Preferential mobilization of PyC particles has received little attention, but a recent study suggests that more highly condensed PyC may be more readily physically degraded in soils due to its physically less stable structure, leaving behind a more biologically available $\mathrm{PyC}$ (Inoue et al., 2017).

\section{SORPTION INTERACTIONS}

The ability for $\mathrm{PyC}$ particles to adsorb non-polar organic compounds lends to its function as a surface adsorption foci in soils, sediments, and solutions (Figure 1). This mechanism has wide ranging implications for how $\mathrm{PyC}$ influences myriad soil processes (Cornelissen and Gustafsson, 2004; Keech et al., 2005; Bornemann et al., 2007; Pingree et al., 2016). First, and perhaps the most obvious, is that most all soluble and mobile organic compounds in soil represent an energy source for microbes. Surface adsorption to $\mathrm{PyC}$ particles would concentrate organic compounds around $\mathrm{PyC}$ particles, thereby creating a microsite for enhanced microbial activity (Lehmann et al., 2011). Increased decomposition of $\mathrm{C}$ adsorbed to PyC may partially account for observations including priming effects (Hamer et al., 2004; Jones et al., 2011), an increase in the nutrient release from mineral precipitates and cation exchange sites, or increased immobilization of inorganic nutrients near $\mathrm{PyC}$ particles. Contrasting findings of $\mathrm{N}$ mineralization and $\mathrm{N}$ immobilization rates (see DeLuca et al., 2015) are likely related to the capacity of PyC to adsorb nutrients and organic compounds. Finally, adsorption of polyphenolic signaling compounds within the rhizosphere could influence plant pathogenic or symbiotic interactions, but to date there has been limited effort to evaluate this in natural ecosystems (Hassan and Mathesius, 2012; Hall et al., 2014; Kolton et al., 2017).

Adsorption capacity is predominantly driven by the specific surface area and pore-size distribution of $\mathrm{PyC}$ particles, which are determined by pyrolysis temperature and the innate chemical nature of the feedstock. As formation temperature increases and pyrolysis or combustion takes place, adsorption capacity typically increases exponentially (Zhu et al., 2005; Brimmer, 2006; Bornemann et al., 2007; Pingree et al., 2016), while pore sizes become dominated by micropores $(<2 \mathrm{~nm}$ ) (Braida et al., 2003; Bornemann et al., 2007). Wood-based PyC contains extensive porosity partly due to the partial pyrolysis of tracheid cells associated with xylem, which contributes further to the natural porosity of PyC made from wood (Keech et al., 2005). Sorption behavior as a function of formation temperature is well-documented in the laboratory (Bornemann et al., 2007), 
but is likely altered by exposure to environmental influences. Direct measurements of adsorption capacity in soils show a more complicated and less predictable relationship between PyC as an adsorbent and naturally-occurring adsorbate compounds (Cornelissen and Gustafsson, 2004; Pingree et al., 2016). Terrestrial and aquatic ecosystems provide complex matrices for sorption interactions that merit a better understanding of sorption interactions in relation to surface properties of PyC.

The adsorption capacity of $\mathrm{PyC}$ as charcoal particles may have a significant effect on $\mathrm{N}$ cycling in post-fire forest soils. Previous studies of temperate and boreal forest soils have shown an increase net mineralization of $\mathrm{N}$ and in net nitrification with the addition of charcoal through the production of nitrate $\left(\mathrm{NO}_{3}^{-}\right.$$\mathrm{N}$ ), which otherwise show minimal net nitrification (DeLuca et al., 2002, 2006; MacKenzie and DeLuca, 2006; Ball et al., 2010; Kurth et al., 2014; Michelotti and Miesel, 2015). There are multiple mechanisms that may be responsible for this observed increase in $\mathrm{NO}_{3}^{-}-\mathrm{N}$ after the addition of charcoal to soil. The presence of $\mathrm{PyC}$ may release nitrifier activity by adsorption of allelopathic $\mathrm{C}$ compounds which results in a total reduction of nitrification potential (Paavolainen et al., 1998; MacKenzie and DeLuca, 2006; Uusitalo et al., 2008). The presence of heterocyclic $\mathrm{C}$ compounds may provide a source of organic $\mathrm{C}$ that results in net immobilization of $\mathrm{NH}_{4}^{+}$(Bremner and McCarty, 1988). In addition, the presence of charcoal may reduce the complexation of high molecular weight compounds and indirectly alter the $\mathrm{N}$ and $\mathrm{C}$ cycles of soils via complexation of $\mathrm{NH}_{4}^{+}$and amines by polyphenolics that may eliminate $\mathrm{NH}_{4}^{+}$ availability for nitrification (Hättenschwiler and Vitousek, 2000). In wildfire-burned chaparral forest soils, the addition of PyC had no significant effect on $\mathrm{N}$ dynamics after an incubation study, but instead may have promoted $\mathrm{N}$ immobilization by enhancing microbial biomass (Hanan et al., 2016). Alternatively, the surface adsorption of $\mathrm{NH}_{4}^{+}$by $\mathrm{PyC}$ could also reduce availability for autotrophic oxidation by nitrifying bacteria-a mechanism yet to be evaluated in $\mathrm{PyC}$ and soil $\mathrm{N}$ dynamics.

The release and reception of molecular signaling compounds is known to directly influence both symbiotic and pathogenic relationships in soils. Both mycorrhizal infection of host plants and nodule establishment in legumes is thought to be dependent upon the release and reception of signaling compounds, which are generally flavonoids or related polyphenolic compounds (Hassan and Mathesius, 2012). It is well-understood that PyC has the capacity to adsorb such compounds (Zackrisson et al., 1996; DeLuca et al., 2002; Keech et al., 2005), but the direct connection between $\mathrm{PyC}$ and signaling effectiveness has, to date, been largely ignored. Biochar-induced ethylene production, a plant hormone and soil microbial inhibitor, has been found in some PyC materials although most notably from non-woody sources (Spokas et al., 2010). Legume nodulation has been observed to both increase and decrease in the presence of biochar applications to surface soils, but more often wood charcoal has increased nodulation or $\mathrm{N}_{2}$ fixation in legumes (see DeLuca et al., 2015). Further, numerous studies have demonstrated an increase in mycorrhizal infection rates in the presence of wood char (Thies et al., 2015). However, there has been no strenuous effort to date to evaluate the influence of $\mathrm{PyC}$ on signaling-mediated processes in natural forest or prairie ecosystems.

\section{MICROSITE EFFECTS}

The presence of $\mathrm{PyC}$ in soils may also serve an important function by creating bioactive zones through the addition of a heterogeneous environment facilitated by the particulate and porous nature of $\mathrm{PyC}$ particles, which provides nutrients, organic matter, water availability, and refuge for some organisms (Figure 1). Pyrogenic C particles have been cited as creating a novel substrate for microbial growth and as physical habitat for microbes (Pietikäinen et al., 2000; Quilliam et al., 2013; Thies et al., 2015), which may aid in the recovery of surface soils exposed to wildfires or intense prescribed fires. $\mathrm{PyC}$ microsites are likely to elicit diverse interactions with surrounding biotic and abiotic constituents in soils as they are most likely to affect plant-microbe-soil interactions in the "charosphere," the soil immediately surrounding a PyC particle (Quilliam et al., 2013).

Surface heterogeneity in naturally-produced PyC particles can further increase soil microorganism activity and abundance via adsorption of compounds utilized as substrate and physical microsites for the exchange of water and gas that may influence redox conditions. While these mechanisms have been evaluated in biochar studies wherein strict pyrolysis conditions and a narrow selection of feedstock were applied to agriculture soils, they have rarely been investigated in natural soils (Briones, 2012; Joseph et al., 2013). Evidence of microbial substrate utilization of adsorbed compounds on PyC surfaces is limited outside of biochar applications, but suggests that surface sorption may play an important role in providing microorganisms with nutrients and $\mathrm{C}$ compounds for metabolic oxidation as well as altering the microbial community (Zackrisson et al., 1996; Singh et al., 2014; Kolton et al., 2017). Negative C mineralization priming in high-temperatureproduced biochar treatments may be related to the adsorption of C substrate (Zimmerman et al., 2011). Additionally, the similarity of dissolved organic matter released by aged $\mathrm{PyC}$ particles to products of polycyclic aromatic hydrocarbon biological decomposition suggests microbial oxidation of PyC (Hockaday et al., 2006, 2007). Enzymatic oxidation of aromatic C structures in lignin, humic acids, and coal are documented and utilized in the bioenergy industry (see review by Fakoussa and Hofrichter, 1999), but have yet to be explored in microbial decomposition of naturally-produced $\mathrm{PyC}$ in soils where regular fire events are likely to sustain the activity of microbial populations responsible for such processes. Studies of ${ }^{14} \mathrm{C}$ labeled biochar mineralization clearly show that $\mathrm{PyC}$ is not resistant to microbial decomposition, however, the interactions between adsorbed substrate utilization and enzymatic oxidation of $\mathrm{PyC}$ remain poorly understood (Hamer et al., 2004; Bruun et al., 2008; Kuzyakov et al., 2009; Jones et al., 2011; Quilliam et al., 2013; Maestrini et al., 2014).

There are numerous examples of microbial hyphae habitation of internal and external $\mathrm{PyC}$ surfaces via pore infiltration. Wildfire-produced PyC exposed to weathering in forest soils over many decades is often physically inhabited by fine roots, filamentous microorganisms, and coated by minerals compared to recently formed PyC (Zackrisson et al., 1996; Hockaday et al., 2007). Internal and external pores on $\mathrm{PyC}$ particles 
have often been cited as providing the potential for microbial habitation as refuge from predators, increasing water holding capacity, providing gas exchange, and increasing redox potential (Lehmann et al., 2011; Thies et al., 2015). However, no quantitative efforts have been undertaken to directly connect microbial abundance, activity, or composition with pore size and distribution of wildfire-deposited PyC particles. Further, PyC and its pore distribution is not a static entity, but an attribute that changes with the numerous physical disturbances presented in terrestrial environment. Subsequent wildfires may further pyrolyze $\mathrm{PyC}$ and physical processes of freezing and thawing, wetting and drying, wind abrasion, or bioturbation all may lead to partial disintegration of $\mathrm{PyC}$ thereby exposing internal surfaces or degrading small pores (Gao et al., 2017). Additionally, the incorporation of $\mathrm{PyC}$ bark from tree boles can provide a delayed input of PyC onto soil surfaces that may exhibit larger pore sizes after prolonged physical weathering (Makoto et al., 2012; Gao et al., 2017).

\section{FUTURE RESEARCH DIRECTIONS}

The historical occurrence of wildfires and anthropogenic fires has yielded a rich ex post facto experimental design of varied length that allows us to evaluate both the recalcitrance of $\mathrm{PyC}$ as well as the functional properties of $\mathrm{PyC}$ in terrestrial

\section{REFERENCES}

Alam, M. S., Cossio, M., Robinson, L., Wang, X., Kenney, J. P. L., Konhauser, K. O., et al. (2016). Removal of organic acids from water using biochar and petroleum coke. Environ. Technol. Innov. 6, 141-151. doi: 10.1016/j.eti.2016.08.005

Archanjo, B. S., Mendoza, M. E., Albu, M., Mitchell, D. R. G., Hagemann, N., Mayrhofer, C., et al. (2017). Nanoscale analyses of the surface structure and composition of biochars extracted from field trials or after co-composting using advanced analytical electron microscopy. Geoderma 294, 70-79. doi: 10.1016/j.geoderma.2017.01.037

Ascough, P. L., Bird, M. I., Francis, S. M., Thornton, B., Midwood, A. J., Scott, A. C., et al. (2011). Variability in oxidative degradation of charcoal: Influence of production conditions and environmental exposure. Geochim. Cosmochim. Acta 75, 2361-2378. doi: 10.1016/j.gca.2011.02.002

Baldock, J. A., and Smernik, R. J. (2002). Chemical composition and bioavailability of thermally altered Pinus resinosa (Red pine) wood. Org. Geochem. 33, 1093-1109. doi: 10.1016/S0146-6380(02)00062-1

Ball, P. N., MacKenzie, M. D., DeLuca, T. H., and Montana, W. E. H. (2010). Wildfire and charcoal enhance nitrification and ammonium-oxidizing bacterial abundance in dry montane forest soils. J. Environ. Qual. 39, 1243-1253. doi: $10.2134 /$ jeq2009.0082

Barrow, C. J. (2012). Biochar: potential for countering land degradation and for improving agriculture. Appl. Geogr. 34, 21-28. doi: 10.1016/j.apgeog.2011.09.008

Bélanger, N., and Pinno, B. D. (2008). Carbon sequestration, vegetation dynamics and soil development in the Boreal Transition ecoregion of Saskatchewan during the Holocene. CATENA 74, 65-72. doi: 10.1016/j.catena.2008.03.005

Bird, M. (2015). “Test procedures for biochar analysis in soils," in Biochar for Environmental Management: Science, Technology and Implementation, 2nd Edn., eds J. Lehmann and S. Joseph (New York, NY: Routledge), 679-716.

Bornemann, L. C., Kookana, R. S., and Welp, G. (2007). Differential sorption behaviour of aromatic hydrocarbons on charcoals prepared at different temperatures from grass and wood. Chemosphere 67, 1033-1042. doi: 10.1016/j.chemosphere.2006.10.052 ecosystems. Knowledge gained from these studies can be used to help elucidate the long-term fate and function of biochar in agricultural soils, which is otherwise limited to "long-term" studies of 10 years or less. Interest in PyC for its role in $\mathrm{C}$ storage has also created a foundation for $\mathrm{C}$ accounting in isolated studies; however, studies lack the use of systematic, consistent approaches to $\mathrm{PyC}$ quantification in post-fire surveys that could provide vital information in a thorough understanding the global C cycle (Parson et al., 2010; Santín et al., 2015). Combining fire ecology, fire science, and PyC research has the potential to directly link wildfire and prescribed fire conditions (such as temperature, duration, fuel load, etc.) to PyC production and characteristics to achieve a better understanding of how fires alter $\mathrm{C}$ dynamics and plant-soil-microbe relationships through the deposition of PyC. Studies of PyC occupy a unique place in science as a focal point in paleobotany, paleoecology, archeology, agriculture, and ecological research for decades, which collectively lend to a multidisciplinary research potential that may lead to a broadened understanding of fire ecology and the role of $\mathrm{PyC}$ in ecosystem diversity and function.

\section{AUTHOR CONTRIBUTIONS}

All authors listed have made a substantial, direct and intellectual contribution to the work, and approved it for publication.

Braida, W. J., Pignatello, J. J., Lu, Y., Ravikovitch, P. I., Neimark, A. V., and Xing, B. (2003). Sorption hysteresis of benzene in charcoal particles. Environ. Sci. Technol. 37, 409-417. doi: 10.1021/es020660z

Bremner, J. M., and McCarty, G. W. (1988). Effects of terpenoids on nitrification in soil. Soil Sci. Soc. Am. J. 52, 1630-1633. doi: 10.2136/sssaj1988.03615995005200060023x

Brimmer, R. J. (2006). Sorption Potential of Naturally Occurring Charcoal in Ponderosa Pine Forests of Western Montana. MS thesis, Missoula, MT: University of Montana.

Briones, A. (2012). The secrets of El Dorado viewed through a microbial perspective. Front. Microbiol. 3:239. doi: 10.3389/fmicb.2012.00239

Bruun, S., Jensen, E. S., and Jensen, L. S. (2008). Microbial mineralization and assimilation of black carbon: Dependency on degree of thermal alteration. Org. Geochem. 39, 839-845. doi: 10.1016/j.orggeochem.2008.04.020

Buma, B., Poore, R. E., and Wessman, C. A. (2014). Disturbances, their interactions, and cumulative effects on carbon and charcoal stocks in a forested ecosystem. Ecosystems 17, 947-959. doi: 10.1007/s10021-014-9770-8

Cheng, C.-H., Lehmann, J., and Engelhard, M. H. (2008). Natural oxidation of black carbon in soils: changes in molecular form and surface charge along a climosequence. Geochim. Cosmochim. Acta 72, 1598-1610. doi: 10.1016/j.gca.2008.01.010

Ciais, P., Sabine, C., Bala, G., Bopp, L., Brovkin, V., Canadell, J., et al. (2013). "Carbon and other biogeochemical cycles," in Climate Change 2013: The Physical Science Basis. Contribution of Working Group I to the Fifth Assessment Report of the Intergovernmental Panel on Climate Change, eds T. F. Stocker, D. Qin, G.-K. Plattner, M. Tignor, S. K. Allen, J. Boschung, A. Nauels, Y. Xia, V. Bex, and P. M. Midgley (Cambridge, New York, NY: Cambridge University Press), 465-570.

Cohen-Ofri, I., Weiner, L., Boaretto, E., Mintz, G., and Weiner, S. (2006). Modern and fossil charcoal: aspects of structure and diagenesis. J. Archaeol. Sci. 33, 428-439. doi: 10.1016/j.jas.2005.08.008

Cornelissen, G., and Gustafsson, Ö. (2004). Sorption of phenanthrene to environmental black carbon in sediment with and without organic matter and native sorbates. Environ. Sci. Technol. 38, 148-155. doi: 10.1021/es034776m 
DeLuca, T. H., Gundale, M. J., MacKenzie, M. D., and Jones, D. L. (2015). "Biochar effects on soil nutrient transformations," in Biochar for Environmental Management: Science, Technology and Implementation, eds J. Lehmann and S. Joseph (New York, NY: Routledge), 421-454.

DeLuca, T. H., MacKenzie, M. D., Gundale, M. J., and Holben, W. E. (2006). Wildfire-produced charcoal directly influences nitrogen cycling in ponderosa pine forests. Soil Sci. Soc. Am. J. 70, 448. doi: 10.2136/sssaj2005.0096

DeLuca, T. H., Nilsson, M., and Zackrisson, O. (2002). Nitrogen mineralization and phenol accumulation along a fire chronosequence in northern Sweden. Oecologia 133, 206-214. doi: 10.1007/s00442-002-1025-2

Dietrich, S. T., MacKenzie, M. D., Battigelli, J. P., and Enterina, J. R. (2017). Building a better soil for upland surface mine reclamation in northern Alberta: admixing peat, subsoil, and peat biochar in a greenhouse study with aspen. Can. J. Soil Sci. doi: 10.1139/CJSS-2017-0021. [Epub ahead of print].

Ding, Y., Cawley, K. M., da Cunha, C. N., and Jaffé, R. (2014). Environmental dynamics of dissolved black carbon in wetlands. Biogeochemistry 119, 259-273. doi: 10.1007/s10533-014-9964-3

Domene, X. (2016). "A critical analysis of meso- and macrofauna effects following biochar supplementation," in Biochar Application: Essential Soil Microbial Ecology, eds T. K. Ralebitso-Senior and C. H. Orr (San Diego, CA: Elsevier), 268-292.

Fakoussa, R. M., and Hofrichter, M. (1999). Biotechnology and microbiology of coal degradation. Appl. Microbiol. Biotechnol. 52, 25-40. doi: $10.1007 / \mathrm{s} 002530051483$

Gao, X., Driver, L. E., Kasin, I., Masiello, C. A., Pyle, L. A., Dugan, B., et al. (2017). Effect of environmental exposure on charcoal density and porosity in a boreal forest. Sci. Total Environ. 592, 316-325. doi: 10.1016/j.scitotenv.2017.03.073

Gavin, D. G., Brubaker, L. B., and Lertzman, K. P. (2003). Holocene fire history of a costal temperate rain forest based on soil charcoal radiocarbon dates. Ecology 84, 186-201. doi: 10.1890/0012-9658(2003)084[0186:HFHOAC2.0.CO;2]

Glaser, B., and Amelung, W. (2003). Pyrogenic carbon in native grassland soils along a climosequence in North America. Glob. Biogeochem. Cycles 17:1064. doi: 10.1029/2002GB002019

Hall, K. E., Calderon, M. J., Spokas, K. A., Cox, L., Koskinen, W. C., Novak, J., et al. (2014). Phenolic acid sorption to biochars from mixtures of feedstock materials. Water Air Soil Pollut. 225:2031. doi: 10.1007/s11270-014-2031-9

Hamer, U., Marschner, B., Brodowski, S., and Amelung, W. (2004). Interactive priming of black carbon and glucose mineralisation. Org. Geochem. 35, 823-830. doi: 10.1016/j.orggeochem.2004.03.003

Hammes, K., Schmidt, M. W. I., Smernik, R. J., Currie, L. A., Ball, W. P., Nguyen, T. H., et al. (2007). Comparison of quantification methods to measure fire-derived (black/elemental) carbon in soils and sediments using reference materials from soil, water, sediment and the atmosphere. Glob. Biogeochem. Cycles 21:GB3016. doi: 10.1029/2006GB002914

Hanan, E. J., Schimel, J. P., Dowdy, K., and D’Antonio, C. M. (2016). Effects of substrate supply, $\mathrm{pH}$, and char on net nitrogen mineralization and nitrification along a wildfire-structured age gradient in chaparral. Soil Biol. Biochem. 95, 87-99. doi: 10.1016/j.soilbio.2015.12.017

Hart, S., and Luckai, N. (2013). REVIEW: Charcoal function and management in boreal ecosystems. J. Appl. Ecol. 50, 1197-1206. doi: 10.1111/1365-2664.12136

Hassan, S., and Mathesius, U. (2012). The role of flavonoids in rootrhizosphere signalling: opportunities and challenges for improving plantmicrobe interactions. J. Exp. Bot. 63, 3429-3444. doi: 10.1093/jxb/err430

Hättenschwiler, S., and Vitousek, P. M. (2000). The role of polyphenols in terrestrial ecosystem nutrient cycling. Trends Ecol. Evol. 15, 238-243. doi: 10.1016/S0169-5347(00)01861-9

Hedges, J. I., Eglinton, G., Hatcher, P. G., Kirchman, D. L., Arnosti, C., Derenne, S., et al. (2000). The molecularly-uncharacterized component of nonliving organic matter in natural environments. Org. Geochem. 31, 945-958. doi: 10.1016/S0146-6380(00)00096-6

Hockaday, W. C., Grannas, A. M., Kim, S., and Hatcher, P. G. (2006). Direct molecular evidence for the degradation and mobility of black carbon in soils from ultrahigh-resolution mass spectral analysis of dissolved organic matter from a fire-impacted forest soil. Org. Geochem. 37, 501-510. doi: 10.1016/j.orggeochem.2005.11.003

Hockaday, W. C., Grannas, A. M., Kim, S., and Hatcher, P. G. (2007). The transformation and mobility of charcoal in a fire-impacted watershed. Geochim. Cosmochim. Acta 71, 3432-3445. doi: 10.1016/j.gca.2007.02.023
Inoue, J., Yoshie, A., Tanaka, T., Onji, T., and Inoue, Y. (2017). Disappearance and alteration process of charcoal fragments in cumulative soils studied using Raman spectroscopy. Geoderma 285, 164-172. doi: 10.1016/j.geoderma.2016.09.032

Jones, D. L., Murphy, D. V., Khalid, M., Ahmad, W., Edwards-Jones, G., and DeLuca, T. H. (2011). Short-term biochar-induced increase in soil CO2 release is both biotically and abiotically mediated. Soil Biol. Biochem. 43, 1723-1731. doi: 10.1016/j.soilbio.2011.04.018

Joseph, S., Graber, E. R., Chia, C., Munroe, P., Donne, S., Thomas, T., et al. (2013). Shifting paradigms: development of high-efficiency biochar fertilizers based on nano-structures and soluble components. Carbon Manage. 4, 323-343. doi: $10.4155 / \mathrm{cmt} .13 .23$

Keech, O., Carcaillet, C., and Nilsson, M.-C. (2005). Adsorption of allelopathic compounds by wood-derived charcoal: the role of wood porosity. Plant Soil 272, 291-300. doi: 10.1007/s11104-004-5485-5

Kleber, M., Hockaday, W. C., and Nico, P. S. (2015). "Characteristics of biochar: macro-molecular properties," in Biochar for Environmental Management: Science, Technology and Implementation, 2nd Edn., eds J. Lehmann and S. Joseph (New York, NY: Routledge), 111-137.

Koide, R. T., Petprakob, K., and Peoples, M. (2011). Quantitative analysis of biochar in field soil. Soil Biol. Biochem. 43, 1563-1568. doi: 10.1016/j.soilbio.2011.04.006

Kolton, M., Graber, E. R., Tsehansky, L., Elad, Y., and Cytryn, E. (2017). Biochar-stimulated plant performance is strongly linked to microbial diversity and metabolic potential in the rhizosphere. New Phytol. 213, 1393-1404. doi: $10.1111 /$ nph.14253

Kurth, V. J., Hart, S. C., Ross, C. S., Kaye, J. P., and Fulé, P. Z. (2014). Standreplacing wildfires increase nitrification for decades in southwestern ponderosa pine forests. Oecologia 175, 395-407. doi: 10.1007/s00442-014-2906-x

Kurth, V. J., MacKenzie, M. D., and DeLuca, T. H. (2006). Estimating charcoal content in forest mineral soils. Geoderma 137, 135-139. doi: 10.1016/j.geoderma.2006.08.003

Kuzyakov, Y., Subbotina, I., Chen, H., Bogomolova, I., and Xu, X. (2009). Black carbon decomposition and incorporation into soil microbial biomass estimated by $14 \mathrm{C}$ labeling. Soil Biol. Biochem. 41, 210-219. doi: 10.1016/j.soilbio.2008.10.016

Laird, D. A., Chappell, M. A., Martens, D. A., Wershaw, R. L., and Thompson, M. (2008). Distinguishing black carbon from biogenic humic substances in soil clay fractions. Geoderma 143, 115-122. doi: 10.1016/j.geoderma.2007.10.025

Lehmann, J., and Joseph, S. (2015). Biochar for Environmental Management: Science, Technology and Implementation. New York, NY: Routledge.

Lehmann, J., Rillig, M. C., Thies, J., Masiello, C. A., Hockaday, W. C., and Crowley, D. (2011). Biochar effects on soil biota-a review. Soil Biol. Biochem. 43, 1812-1836. doi: 10.1016/j.soilbio.2011.04.022

Liang, B., Lehmann, J., Solomon, D., Sohi, S., Thies, J. E., Skjemstad, J. O., et al. (2008). Stability of biomass-derived black carbon in soils. Geochim. Cosmochim. Acta 72, 6069-6078. doi: 10.1016/j.gca.2008.09.028

Licata, C., and Sanford, R. (2012). Charcoal and total carbon in soils from foothills shrublands to subalpine forests in the Colorado front range. Forests 3:944. doi: 10.3390/f3040944

MacKenzie, M. D., and DeLuca, T. H. (2006). Charcoal and shrubs modify soil processes in ponderosa pine forests of western Montana. Plant Soil 287, 257-266. doi: 10.1007/s11104-006-9074-7

MacKenzie, M. D., McIntire, E. J. B., Quideau, S. A., and Graham, R. C. (2008), Charcoal distribution affects carbon and nitrogen contents in forest soils of California. Soil Sci. Soc. Am. J. 72, 1774-1785. doi: 10.2136/sssaj2007.0363

Maestrini, B., Herrmann, A. M., Nannipieri, P., Schmidt, M. W. I., and Abiven, S. (2014). Ryegrass-derived pyrogenic organic matter changes organic carbon and nitrogen mineralization in a temperate forest soil. Soil Biol. Biochem. 69, 291-301. doi: 10.1016/j.soilbio.2013.11.013

Makoto, K., Kamata, N., Kamibayashi, N., Koike, T., and Tani, H. (2012). Barkbeetle-attacked trees produced more charcoal than unattacked trees during a forest fire on the Kenai Peninsula, Southern Alaska. Scand. J. For. Res. 27, 30-35. doi: 10.1080/02827581.2011.619566

Meyer, G. A., Wells, S. G., and Jull, A. T. (1995). Fire and alluvial chronology in Yellowstone National Park: climatic and intrinsic controls on Holocene geomorphic processes. Geol. Soc. Am. Bull. 107, 1211-1230. doi: 10.1130/0016-7606(1995)107andlt;1211:FAACIYandgt;2.3.CO;2 
Michelotti, L., and Miesel, J. (2015). Source material and concentration of wildfireproduced pyrogenic carbon influence post-fire soil nutrient dynamics. Forests 6:1325. doi: $10.3390 / \mathrm{f} 6041325$

Miesel, J. R., Hockaday, W. C., Kolka, R. K., and Townsend, P. A. (2015). Soil organic matter composition and quality across fire severity gradients in coniferous and deciduous forests of the southern boreal region. J. Geophys. Res. Biogeosci. 120, 1124-1141. doi: 10.1002/2015JG002959

Mikutta, R., Kleber, M., Kaiser, K., and Jahn, R. (2005). Review: organic matter removal from soils using hydrogen peroxide, sodium hypochlorite, and disodium peroxodisulfate. Soil Sci. Soc. Am. J. 69, 120-135. doi: $10.2136 /$ sssaj2005.0120

Nguyen, B. T., Lehmann, J., Kinyangi, J., Smernik, R., Riha, S. J., and Engelhard, M. H. (2008). Long-term black carbon dynamics in cultivated soil. Biogeochemistry 92, 163-176. doi: 10.1007/s10533-008-9248-x

Nishimiya, K., Hata, T., Imamura, Y., and Ishihara, S. (1998). Analysis of chemical structure of wood charcoal by X-ray photoelectron spectroscopy. J. Wood Sci. 44, 56-61. doi: 10.1007/BF00521875

Paavolainen, L., Kitunen, V., and Smolander, A. (1998). Inhibition of nitrification in forest soil by monoterpenes. Plant Soil 205, 147-154. doi: 10.1023/A:1004335419358

Parson, A., Robichaud, P. R., Lewis, S. A., Napper, C., and Clark, J. T. (2010). Guide for Mapping Post-Fire Soil Burn Severity. USFS Rocky Mountain Research Station, Fort Collins, CO.

Pierson, H. O. (1993). Handbook of Carbon, Graphite, Diamonds and fullerenes: Processing, Properties and Applications. Park Ridge, NJ: Noyes Publications.

Pietikäinen, J., Kiikkilä, O., and Fritze, H. (2000). Charcoal as a habitat for microbes and its effect on the microbial community of the underlying humus. Oikos 89, 231-242. doi: 10.1034/j.1600-0706.2000.890203.x

Pingree, M. R. A., DeLuca, E. E., Schwartz, D. T., and DeLuca, T. H. (2016). Adsorption capacity of wildfire-produced charcoal from Pacific Northwest forests. Geoderma 283, 68-77. doi: 10.1016/j.geoderma.2016.07.016

Pingree, M. R. A., Homann, P. S., Morrissette, B., and Darbyshire, R. (2012). Long and short-term effects of fire on soil charcoal of a conifer forest in southwest Oregon. Forests 3, 353-369. doi: 10.3390/f3020353

Preston, C. M., and Schmidt, M. W. I. (2006). Black (pyrogenic) carbon: a synthesis of current knowledge and uncertainties with special consideration of boreal regions. Biogeosciences 3, 397-420. doi: 10.5194/bg-3-397-2006

Quilliam, R. S., Glanville, H. C., Wade, S. C., and Jones, D. L. (2013). Life in the 'charosphere'-does biochar in agricultural soil provide a significant habitat for microorganisms? Soil Biol. Biochem. 65, 287-293. doi: 10.1016/j.soilbio.2013.06.004

Reisser, M., Purves, R. S., Schmidt, M. W. I., and Abiven, S. (2016). Pyrogenic carbon in soils: a literature-based inventory and a global estimation of its content in soil organic carbon and stocks. Front. Earth Sci. 4:80. doi: 10.3389/feart.2016.00080

Rovira, P., and Ramón Vallejo, V. (2007). Labile, recalcitrant, and inert organic matter in Mediterranean forest soils. Soil Biol. Biochem. 39, 202-215. doi: 10.1016/j.soilbio.2006.07.021

Santín, C., Doerr, S. H., Preston, C. M., and González-Rodríguez, G. (2015). Pyrogenic organic matter production from wildfires: a missing sink in the global carbon cycle. Glob. Chang. Biol. 21, 1621-1633. doi: 10.1111/gcb.12800

Schneider, M. P. W., Hilf, M., Vogt, U. F., and Schmidt, M. W. I. (2010). The benzene polycarboxylic acid (BPCA) pattern of wood pyrolyzed between $200^{\circ} \mathrm{C}$ and $1000^{\circ} \mathrm{C}$. Org. Geochem. 41, 1082-1088. doi: 10.1016/j.orggeochem.2010.07.001
Scott, A. C. (2000). The Pre-Quaternary history of fire. Palaeogeography 164, 281-329. doi: 10.1016/S0031-0182(00)00192-9

Singh, B. P., Cowie, A. L., and Smernik, R. J. (2012). Biochar carbon stability in a clayey soil as a function of feedstock and pyrolysis temperature. Environ. Sci. Technol. 46, 11770-11778. doi: 10.1021/es302545b

Singh, N., Abiven, S., Maestrini, B., Bird, J. A., Torn, M. S., and Schmidt, M. W. I. (2014). Transformation and stabilization of pyrogenic organic matter in a temperate forest field experiment. Glob. Chang. Biol. 20, 1629-1642. doi: $10.1111 /$ gcb. 12459

Sohi, S. P., Krull, E., Lopez-Capel, E., and Bol, R. (2010). "Chapter 2-a review of biochar and its use and function in soil," in Advances in Agronomy, ed D. E. Sparks (San Diego, CA: Academic Press), 47-82.

Soucémarianadin, L. N., Quideau, S. A., and MacKenzie, M. D. (2014). Pyrogenic carbon stocks and storage mechanisms in podzolic soils of fire-affected Quebec black spruce forests. Geoderma 217-218, 118-128. doi: 10.1016/j.geoderma.2013.11.010

Spokas, K. A., Baker, J. M., and Reicosky, D. C. (2010). Ethylene: potential key for biochar amendment impacts. Plant Soil 333, 443-452. doi: 10.1007/s11104-010-0359-5

Thies, J. E., Rillig, M. C., and Graber, E. R. (2015). "Biochar effects on the abundance, activity and diversity of the soil biota," in Biochar for Environmental Management: Science, Technology and Implementation, eds J. Lehmann and S. Joseph (New York, NY: Routledge), 327-390.

Tinkham, W. T., Smith, A. M. S., Higuera, P. E., Hatten, J. A., Brewer, N. W., and Doerr, S. H. (2016). Replacing time with space: using laboratory fires to explore the effects of repeated burning on black carbon degradation. Int. J. Wildland Fire 25, 242-248. doi: 10.1071/WF15131

Uusitalo, M., Kitunen, V., and Smolander, A. (2008). Response of C and N transformations in birch soil to coniferous resin volatiles. Soil Biol. Biochem. 40, 2643-2649. doi: 10.1016/j.soilbio.2008.07.009

Zackrisson, O., Nilsson, M.-C., and Wardle, D. A. (1996). Key ecological function of charcoal from wildfire in the Boreal forest. Oikos 77, 10-19. doi: $10.2307 / 3545580$

Zhu, D., Kwon, S., and Pignatello, J. J. (2005). Adsorption of single-ring organic compounds to wood charcoals prepared under different thermochemical conditions. Environ. Sci. Technol. 39, 3990-3998. doi: 10.1021/es0 $50129 \mathrm{e}$

Zimmerman, A. R. (2010). Abiotic and microbial oxidation of laboratoryproduced black carbon (biochar). Environ. Sci. Technol. 44, 1295-1301. doi: 10.1021/es903140c

Zimmerman, A. R., Gao, B., and Ahn, M.-Y. (2011). Positive and negative carbon mineralization priming effects among a variety of biocharamended soils. Soil Biol. Biochem. 43, 1169-1179. doi: 10.1016/j.soilbio.2011. 02.005

Conflict of Interest Statement: The authors declare that the research was conducted in the absence of any commercial or financial relationships that could be construed as a potential conflict of interest.

Copyright (c) 2017 Pingree and DeLuca. This is an open-access article distributed under the terms of the Creative Commons Attribution License (CC BY). The use, distribution or reproduction in other forums is permitted, provided the original author(s) or licensor are credited and that the original publication in this journal is cited, in accordance with accepted academic practice. No use, distribution or reproduction is permitted which does not comply with these terms. 